\title{
The effect of teicoplanin on fracture healing: an experimental study
}

\author{
Teikoplanin'in kırık iyileşmesi üzerine etkisi: Deneysel çalışma
}

\author{
Hasan Göçer, MD., ${ }^{1}$ Mehmet Emin Önger, MD., ${ }^{2}$ Numan Kuyubaşı, MD., ${ }^{1}$ \\ Alper Çıraklı, MD., ${ }^{3}$ Mustafa Çağlar Kır, MD. ${ }^{4}$

\begin{abstract}
'Department of Orthopedics and Traumatology, Medical Faculty of Ondokuz Mayıs University, Samsun, Turkey ${ }^{2}$ Department of Histology and Embriology, Medical Faculty of Ondokuz Mayıs University, Samsun, Turkey ${ }^{3}$ Department of Orthopedics and Traumatology, Kayseri Training and Research Hospital, Kayseri, Turkey ${ }^{4}$ Department of Orthopedics and Traumatology, Medical Faculty of Celal Bayar University, Manisa, Turkey
\end{abstract}

\begin{abstract}
Objectives: This study aims to investigate the effect of teicoplanin on fracture healing stereologically and histopatologically.

Materials and methods: Twenty male Wistar albino rats were separated into two as the study (teicoplanin) and control groups. After intramedullary fixation of the right tibia of all the rats with $0.5 \mathrm{~mm}$ Kirschner wire under general anesthesia, standard closed shaft fractures were created using fracture formation apparatus. Teicoplanin $(10 \mathrm{mg} / \mathrm{kg})$ and saline were administered intraperitoneally to the study and control groups, respectively. Control radiographs were taken at the end of the procedure and the rats were sacrificed after 28 days. New bone and connective tissue volumes were calculated on obtained tissue samples using unbiased stereological and histopathological techniques.
\end{abstract}

Results: It was observed that teicoplanin increased the formation of bone, vascularization, and connective tissue. There was a statistically significant difference between the two groups in respect of bone and vascular total volume $(\mathrm{p}<0.05)$. Although an increase was observed in connective tissue total volume, no statistically significant difference was detected between the two groups ( $\mathrm{p}>0.05)$.

Conclusion: In addition to its antibacterial effect, teicoplanin may increase new bone formation; thus, it may be used safely in the treatment of bone defects accompanied with infection.

Keywords: Closed fracture; fracture healing; rat; teicoplanin; tibia fracture.

Permanent morbidity and mortality caused by failed fracture healing and infections in bone and prosthesis are still significant problems in orthopedic practice. ${ }^{[1,2]}$

\section{$O ̈ Z$}

Amaç: $\mathrm{Bu}$ çalışmada teikoplanin'in kırık iyileşmesi üzerine etkisi stereolojik ve histopatolojik olarak incelendi.

Gereç ve yöntemler: Yirmi adet Wistar-albino erkek sıçan çalışma (teikoplanin) ve kontrol grubu olarak ikiye ayrıldı. Genel anestezi altında tüm sıçanların sağ tibiaları intramedüller olarak $0.5 \mathrm{~mm}$ 'lik Kirschner teli ile tespit edildikten sonra kırık oluşturma aparatı ile standart kapalı cisim kırıkları oluşturuldu. Çalışma ve kontrol grubuna intraperitoneal olarak sirasiyla $10 \mathrm{mg} / \mathrm{kg}$ teikoplanin ve serum fizyolojik uygulandı. İşlem sonunda kontrol grafileri çekildi ve 28 gün sonra tüm sıçanlar sakrifiye edildi. Elde edilen doku örnekleri üzerinde tarafsız stereolojik ve histopatolojik yöntemler kullanılarak yeni kemik ve bağ doku hacimleri hesapland1.

Bulgular: Teikoplanin'in kemik, damar ve bağ dokusu oluşumunu artırdığı gözlendi. Kemik ve damar total hacminde iki grup arasında istatistiksel olarak anlamlı farklılık vardı $(\mathrm{p}<0.05)$. Bağ doku total hacminde artış gözlenmesine rağmen iki grup arasında istatistiksel olarak anlamlı bir farklılık saptanmadi $(\mathrm{p}>0.05)$.

Sonuç: Teikoplanin antibakteriyel etkisinin yanı sıra yeni kemik oluşumunu artırabilir; böylelikle, enfeksiyonla birlikte görülen kemik defektlerinin tedavisinde güvenle kullanılabilir. Anahtar sözcükler: Kapalı kırık; kırık iyileşmesi; sıçan; teikoplanin; tibia kırı̆̆ı.

Broad-spectrum antibiotics or combinations of more than one antibiotic are used for the treatment of such infections. Experimental studies have been carried

- Received: October 14, 2015 Accepted: November 24, 2015

- Correspondence: Numan Kuyubaşı, M.D. Ondokuz Mayıs Üniversitesi Tıp Fakültesi Ortopedi ve Travmatoloji Anabilim Dalı, 55139 Kurupelit, Samsun, Tel: +90 507 - 3063966 Fax: +90362 - 4576091 e-mail: s.numankuyubasi@hotmail.com 
out to investigate the effects of several factors on fracture healing. ${ }^{[3,4]}$ Teicoplanin is a broad spectrum antibiotic used alone or together with other antibiotics in many circumstances where the agent is unknown or in infections associated with methicillin-resistant coagulase (-) Staphylococcus aureus in gram (+) aerobic and anaerobic organisms. ${ }^{[5]}$ This antibiotic can be used either systemically or locally together with antibiotic cement for the control of orthopedic infections. A review of the literature did not reveal any study regarding the effect of teicoplanin on fracture healing. Therefore, in this study, we aimed to investigate the effect of teicoplanin on fracture healing stereologically and histopatologically.

\section{MATERIALS AND METHODS}

This study was conducted between April 2014 and December 2014 at Ondokuz Mayis University Experimental Animal Research and Applying Center. Approval for the study was granted by the local ethics committee. All the procedures were applied in conformity with the experimental animals ethics guidelines. A total of 20 male Wistar albino rats, weighing 250-300 gr were used. The rats were placed in special cages with plastic bases and covered with wire. Throughout the study, the rats were kept at room temperature $\left(22 \pm 2{ }^{\circ} \mathrm{C}\right)$ at $40 \%-50 \%$ humidity and under a 12-hour light-dark cycle. Rats were fed standard rat pellets and tap water. Using the random sampling method, rats were separated into two groups of 10 (study and control groups). A fracture was created in the right tibia bone of each rat. Then, teicoplanin $(10 \mathrm{mg} / \mathrm{kg})$ and saline were administered intraperitoneally to the study and control groups, respectively.

\section{Surgical procedure}

Anesthesia was applied to all rats with intraperitoneal application (10 mg/100 mg bodyweight) of ketamine $\left(50 \mathrm{mg} / \mathrm{mL}\right.$ Ketalar $^{\circledR}$, Pfizer, Istanbul) and (10 mg/100 mg bodyweight) prilocaine hydrochloride $\left(2 \%\right.$, Citanest ${ }^{\circledR}$, Astra Zeneca, Istanbul). Thirty minutes before the procedure, cefazoline sodium $(15 \mathrm{mg} / \mathrm{kg})$ was applied intramuscularly. When full anesthesia was achieved, the relevant area was shaved and antiseptic was applied. The knee was opened with an approximately $2 \mathrm{~cm}$ midline incision, the patella was protected to the lateral and fixation was made with a $0.5 \mathrm{~mm}$ Kirschner wire (Figure 1). Following fixation, a fracture was created with the fracture apparatus described by Tatari et al., ${ }^{[6]}$ then radiographs were taken to check the fracture and the fixation (Figure 2). On the $28^{\text {th }}$ day of the study, radiographs were taken, after which the rats were sacrificed.

\section{Stereological method}

According to the rules of systemic random sampling, parallel and serial coronal sections of equal length were used to calculate the involved volume and area. This interval is defined from the basic principles of stereology by taking the 'error coefficient' into consideration. The measurement of area points was organized as points at $50 \mu \mathrm{m}$ intervals on the ruler. The total volumes of the sections were measured using the point counting method with the Cavalieri's principle at magnification $x 10$ on the computer-assisted system and by examining parameters such as newly-formed bone, vessels, and connective tissue. The Cavalieri's principle is a method of calculating the volume of a structure separated into parallel slices at equal intervals. Calculations made with this method have shown no difference from calculations made with advanced imaging analysis systems in respect of precision and accuracy. An advantage of the stereological method is that the amount of error of the study can be calculated before the study. The relationship between the structure and the measuring ruler used is highly significant in
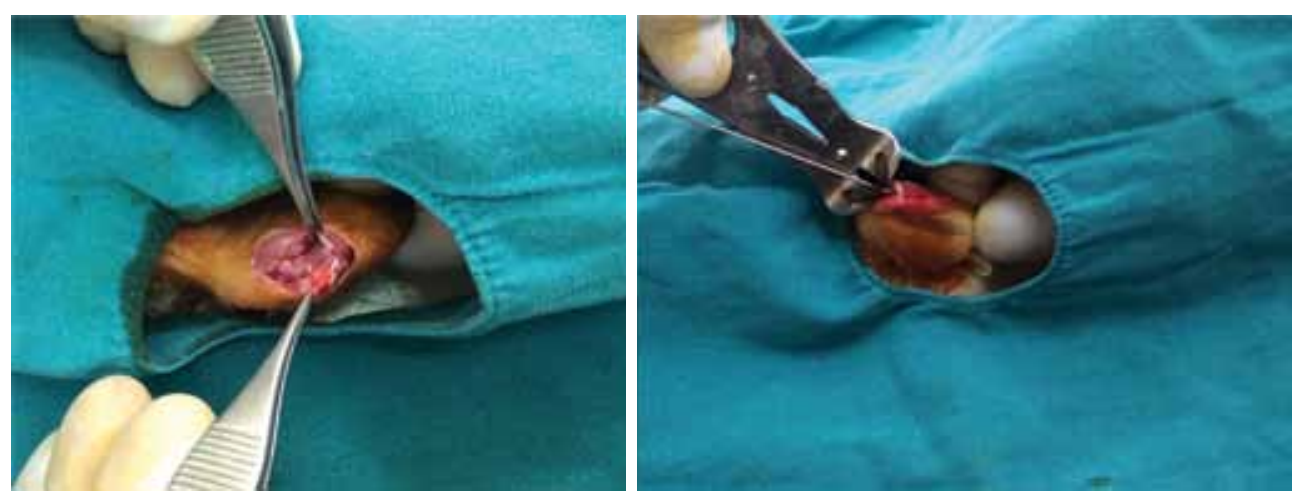

Figure 1. Right knee was opened with an approximately $2 \mathrm{~cm}$ midline incision, patella was protected, and fixation was made with a $0.5 \mathrm{~mm}$ intramedullary Kirschner wire in tibia. 


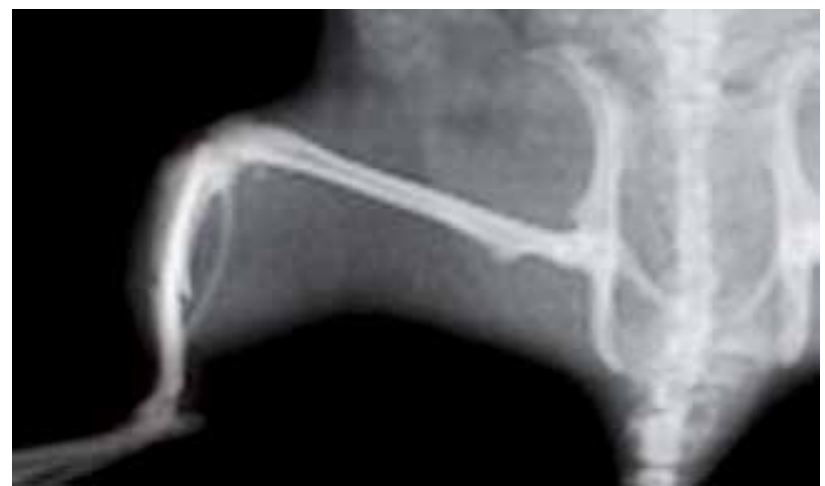

Figure 2. After fracture was created with fracture apparatus, radiographs were taken to check tibial fracture and fixation.

terms of precision and accuracy of the sampling and calculations.

Histopathological method: The tibia samples obtained from the groups were fixed for one week in $10 \%$ formalin $(10 \mathrm{~mL} 40 \%$ formaldehyde, $90 \mathrm{~mL}$ distilled water). Then, the tissues were decalcified in a $5 \%$ formic acid solution at room temperature for a period of 21 days. During the decalcification procedure, the hardness of the tissues was checked at three-day intervals and the solution was refreshed. Following this procedure, the tissues were washed in distilled water, then passed through a series of graduated alcohol, then cleared with a series of xylene, and finally embedded in fresh paraffin blocks. Coronal series sections of $5 \mu \mathrm{m}$ thickness were taken on to glass slides as $1 / 50$ sampling from the paraffin tissue blocks. For a histological evaluation of the structure, they were incubated overnight at $60{ }^{\circ} \mathrm{C}$ in the incubator, and, after deparaffinization in xylene, the rehydration procedure was applied followed by staining with hematoxylin-eosin. All the stained sections were covered with Entellan (Merck KGaA, Darmstadt, Germany) and examined under a Leica DM4000 light microscope (Leica Microsystems CMS GmbH, Wetzlar, Germany).
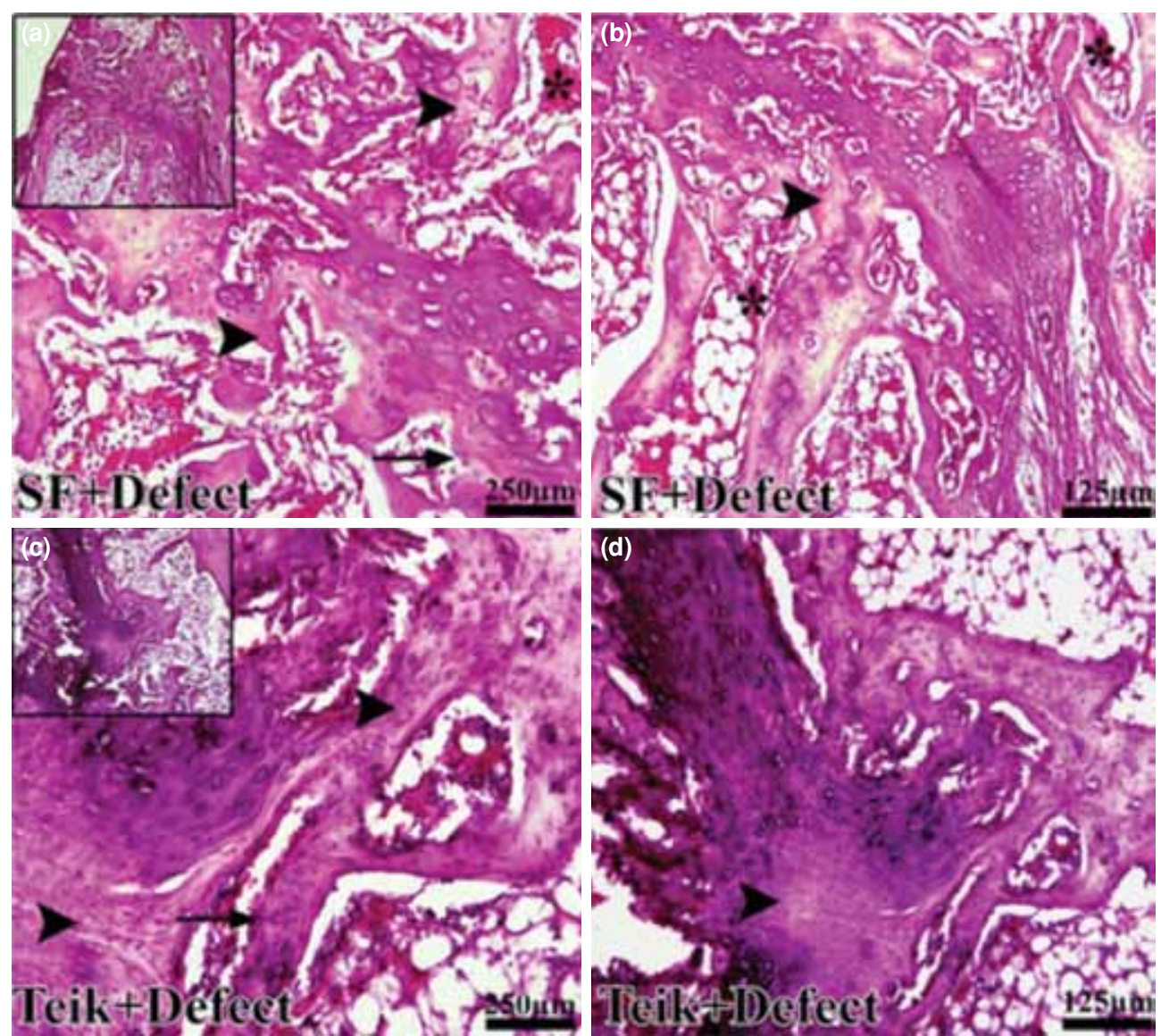

Figure 3. Representative images obtained for histopathological evaluation at $x 5, x 10$, and $x 20$ magnifications. Black arrows indicate intense osteoblastic activity around new bone for SF + defect (control) and Teik + defect (study) groups. Head of black arrows show area of new bone regeneration in both groups. Vessel density is shown by asterisks $\left(^{*}\right)$ in SF + defect (control) group. Scale bars: $250 \mu \mathrm{m}$ and $125 \mu \mathrm{m}$. 


\section{RESULTS}

Teicoplanin enhanced the formation of bone, vessels, and connective tissue (Figure 3). An analysis of this effect revealed a statistically significant difference between the two groups in respect of bone and vascular total volume $(p<0.05)$. Although an increase was observed in connective tissue total volume between the two groups, the difference was not statistically significant $(\mathrm{p}>0.05)$. All stereological results are summarized in Table 1.

\section{DISCUSSION}

The stages of fracture healing are known to be an extremely complex process. ${ }^{[7,8]}$ There are several factors that affect fracture healing. Some of these are patientrelated such as ageing, chronic disease, and used medications while some are related to the severity of the injury and the treatment type. ${ }^{[9-11]}$ Several antibiotics are clinically used alone or in combined form both as prophylaxis and in the treatment of infection. The effect of antibiotics on fracture healing has been investigated in previous studies, with some showing positive or negative effects and some showing no effect. ${ }^{[12-14]}$ However, to the best of our knowledge, no previous study exits on the effect of teicoplanin on fracture healing, which is a frequently used antibiotic in clinical practice.

Teicoplanin is a broad spectrum antibiotic that is used against methicillin-resistant Staphylococcus aureus and coagulase (-) staphylococcus. This antibiotic can easily penetrate to the bone. ${ }^{[15]}$ It was reported that the addition of calcium sulfate to polymethylmethacrylate-loaded teicoplanin increased antibiotic expression and decreased the bacterial adhesion. ${ }^{[16]}$ In our study, the new bone areas increased statistically significantly in teicoplanin group, which may indicate osteogenesis and osseointegration triggered by teicoplanin.

Osteoblasts form mineralized osteoid. While osteoprogenitor cells do not play a role in the physiological development of bone, they function in regeneration after trauma. Since the total amount of connective tissue infiltration volume was higher in teicoplanin group compared to control group, we may conclude that teicoplanin increased new bone areas as a result of increased amount of connective tissue infiltration.

Although investigations on the presence and amount of progenitor cells in connective tissue compound using immunohistochemical staining would contribute to future studies, we suggest that teicoplanin may increase angiogenesis via different mechanisms as a result of increased total volume of capillaries.

Quinolone group antibiotics are often used in osteomyelitis and urinary system, soft tissue, and periprosthetic infections. Previous studies of quinolone group antibiotics have shown decreased bone healing and new bone formation. In in vivo studies, this effect has been shown to be the result of the prevention of osteoblast and chondrocyte synthesis and proliferation. ${ }^{[13,17-20]}$ Holtom et al. ${ }^{[20]}$ showed that bone formation was inhibited by preventing the accumulation of calcium in an in vitro study. Antoci et al. ${ }^{[21]}$ demonstrated that osteoblasts and chondroblasts were reduced by impairing cell membrane functions.

In various studies, cefazolin sodium, which is the most widely used prophylaxis in all surgical branches, has been reported to have no effect on fracture healing or to have a positive effect. ${ }^{[13,19,22]}$ However, how this effect has been achieved has not been shown.

Salzman et al. ${ }^{[23]}$ used high doses of cefuroxime locally in the osteoblast environment and demonstrated increased new bone formation by elevation of alkaline phosphatase level. It has been suggested that, due to this feature, cefuroxime combined with cement could be used clinically to increase the periprosthetic new bone formation.

TABLE I

Total volumes of new bone, vessel, and connective tissue

\begin{tabular}{|c|c|c|}
\hline \multirow{3}{*}{ Estimation } & \multicolumn{2}{|c|}{ Groups } \\
\hline & Surgery+Saline & Surgery+Teicoplanin \\
\hline & Mean \pm SE & Mean \pm SE \\
\hline New bone total volume $\left(\mathrm{mm}^{3}\right)$ & $1.253 \pm 0.137$ & $1.622 \pm 0.082$ \\
\hline Blood vessels total volume $\left(\mathrm{mm}^{3}\right)$ & $0.050 \pm 0.006$ & $0.084 \pm 0.006$ \\
\hline Connective tissue total volume $\left(\mathrm{mm}^{3}\right)$ & $1.110 \pm 0.110$ & $1.350 \pm 0.150$ \\
\hline
\end{tabular}


Benefits might be obtained from antibacterial properties with the local application of teicoplanin combined with cement in infections developing after arthroplasty surgery and osteomyelitis. ${ }^{[2,25]}$ In the current study, teicoplanin was observed to increase new bone formation. In this respect, teicoplanin may be useful in increasing new bone formation in the treatment of bone defects after osteomyelitis treatment or revision arthroplasty surgery.

Haleem et al. ${ }^{[14]}$ reported that vancomycin and gentamicin have no beneficial effect on fracture healing. Furthermore, Eder et al. ${ }^{[2]}$ examined the toxic effect of different concentrations of vancomycin and showed that new bone formation was inhibited at high doses through the impairment of migration, proliferation, and differentiation of osteoblasts.

In a study by Masquelet, ${ }^{[27]}$ it was shown that the pseudo fibrotic connective tissue filled with bone cement increased the formation of new bone. Pelissier et al. ${ }^{[28]}$ reported a greater amount of osteoinductive and osteoconductive factors in the pseudosynovial membrane which formed around the cement and suggested that new bone formation was increased in this way. In the current study, more fibrotic connective tissue was observed around the fracture in the teicoplanin group compared to the control group. This fibrotic connective tissue, which forms around the fracture, might trigger fracture healing and new bone formation. Adding teicoplanin to the bone cement using Masquelet's method for extensive bone defects may lead to more new bone formation by increasing the fibrotic connective tissue infiltration. ${ }^{[27]}$

Fracture hematoma and angiogenesis are of critical importance in fracture healing and new bone formation. Angiogenesis in the fracture area undertakes the important function of transporting metabolic substances both within the callus and to the area increasing osteogenesis. ${ }^{[24,29]}$ In the current study, the increased angiogenesis in the fracture area of the teicoplanin group might be the reason for the increased fracture healing and new bone formation compared to the control group. With this effect, teicoplanin may be safely used in cases of infection which require new bone formation.

The positive or negative effects of antibiotics on the body vary according to the dose of antibiotic administered..$^{[13,30]}$ In a study by Zhang et al., ${ }^{[31]}$ seven different concentrations of rifampicin were used locally on cell cultures and it was shown that high doses prevented the proliferation of mesenchymal stem cells and osteoblast differentiation. Although antibacterial dose of teicoplanin is well known, further studies are required in order to establish the ideal dose which covers bone regenerative effect.

There are some limitations to this study including the lack of mechanical tests and measurements of osteoblastic activity markers such as alkaline phosphatase, type 1 collagen, and osteonectin as well as the serum antibiotic level.

In conclusion, the results of this study showed that teicoplanin may increase formation of new bone, vascular, and connective tissue. Therefore, it may be used in cases where the bone is weak or where there is bone defect accompanied with infection. Further studies are required to demonstrate the positive effects teicoplanin.

\section{Declaration of conflicting interests}

The authors declared no conflicts of interest with respect to the authorship and/or publication of this article.

\section{Funding}

The authors received no financial support for the research and/or authorship of this article.

\section{REFERENCES}

1. Mujagic E, Zwimpfer T, Marti WR, Zwahlen M, Hoffmann $\mathrm{H}$, Kindler $\mathrm{C}$, et al. Evaluating the optimal timing of surgical antimicrobial prophylaxis: study protocol for a randomized controlled trial. Trials 2014;15:188.

2. Xu SG, Mao ZG, Liu BS, Zhu HH, Pan HL. Evaluating the use of antibiotic prophylaxis during open reduction and internal fixation surgery in patients at low risk of surgical site infection. Injury 2015;46:184-8.

3. Oktaş B, Orhan Z, Erbil B, Değirmenci E, Ustündağ N. Effect of extracorporeal shock wave therapy on fracture healing in rat femural fractures with intact and excised periosteum. Eklem Hastalik Cerrahisi 2014;25:158-62.

4. Toğral G, Arıkan M, Korkusuz P, Hesar RH, Ekşioğlu MF. Positive effect of tadalafil, a phosphodiesterase-5 inhibitor, on fracture healing in rat femur. Eklem Hastalik Cerrahisi 2015;26:137-44.

5. Soriano A, Popescu D, García S, Bori G, Martínez JA, Balasso $\mathrm{V}$, et al. Usefulness of teicoplanin for preventing methicillin-resistant Staphylococcus aureus infections in orthopedic surgery. Eur J Clin Microbiol Infect Dis 2006;25:35-8.

6. Tatari H, Fidan M, Erbil G, Koyuncuoglu M, Karci T, Destan $\mathrm{H}$, et al. A new device to produce a standardized experimental fracture in the rat tibia. Saudi Med J 2007;28:866-71.

7. Ulstrup AK. Biomechanical concepts of fracture healing in weight-bearing long bones. Acta Orthop Belg 2008;74:291-302.

8. Shapiro F. Bone development and its relation to fracture repair. The role of mesenchymal osteoblasts and surface osteoblasts. Eur Cell Mater 2008;15:53-76.

9. Egol KA, Bechtel C, Spitzer AB, Rybak L, Walsh M, Davidovitch R. Treatment of long bone nonunions: factors 
affecting healing. Bull NYU Hosp Jt Dis 2012;70:224-31.

10. Preston CF, Egol KA. Midshaft clavicle fractures in adults. Bull NYU Hosp Jt Dis 2009;67:52-7.

11. Green E, Lubahn JD, Evans J. Risk factors, treatment, and outcomes associated with nonunion of the midshaft humerus fracture. J Surg Orthop Adv 2005;14:64-72.

12. Akkaya S, Nazalı M, Kılıç A, Bir F. Cefazolin-sodium has no adverse effect on fracture healing in an experimental rabbit model. Eklem Hastalik Cerrahisi 2012;23:44-8.

13. Rathbone CR, Cross JD, Brown KV, Murray CK, Wenke JC. Effect of various concentrations of antibiotics on osteogenic cell viability and activity. J Orthop Res 2011;29:1070-4.

14. Haleem AA, Rouse MS, Lewallen DG, Hanssen AD, Steckelberg JM, Patel R. Gentamicin and vancomycin do not impair experimental fracture healing. Clin Orthop Relat Res 2004;427:22-4.

15. Periti P, Mini E, Mosconi G. Antimicrobial prophylaxis in orthopaedic surgery: the role of teicoplanin. J Antimicrob Chemother 1998;41:329-40.

16. Yaniv M, Dabbi D, Amir H, Cohen S, Mozes M, Tsuberi $\mathrm{H}$, et al. Prolonged leaching time of peptide antibiotics from acrylic bone cement. Clin Orthop Relat Res 1999;363:232-9.

17. Urist MR, McLean FC. Osteogenetic potency and newbone formation by induction in transplants to the anterior chamber of the eye. J Bone Joint Surg [Am] 1952;34:443-76.

18. Tuncay I, Ozbek H, Köşem M, Unal O. A comparison of effects of fluoroquinolones on fracture healing (an experimental study in rats). Ulus Travma Acil Cerrahi Derg 2005;11:17-22.

19. Huddleston PM, Steckelberg JM, Hanssen AD, Rouse MS, Bolander ME, Patel R. Ciprofloxacin inhibition of experimental fracture healing. J Bone Joint Surg [Am] 2000;82:161-73.

20. Holtom PD, Pavkovic SA, Bravos PD, Patzakis MJ, Shepherd LE, Frenkel B. Inhibitory effects of the quinolone antibiotics trovafloxacin, ciprofloxacin, and levofloxacin on osteoblastic cells in vitro. J Orthop Res 2000;18:721-7.

21. Antoci V Jr, Adams CS, Hickok NJ, Shapiro IM, Parvizi J. Antibiotics for local delivery systems cause skeletal cell toxicity in vitro. Clin Orthop Relat Res 2007;462:200-6.

22. Bicanic G, Crnogaca K, Barbaric K, Delimar D. Cefazolin should be administered maximum 30 min before incision in total knee arthroplasty when tourniquet is used. Med Hypotheses 2014;82:766-8.

23. Salzmann GM, Naal FD, von Knoch F, Tuebel J, Gradinger $\mathrm{R}$, Imhoff $\mathrm{AB}$, et al. Effects of cefuroxime on human osteoblasts in vitro. J Biomed Mater Res A 2007;82:462-8.

24. Chang Y, Chen WC, Hsieh PH, Chen DW, Lee MS, Shih $\mathrm{HN}$, et al. In vitro activities of daptomycin-, vancomycin-, and teicoplanin-loaded polymethylmethacrylate against methicillin-susceptible, methicillin-resistant, and vancomycin-intermediate strains of Staphylococcus aureus. Antimicrob Agents Chemother 2011;55:5480-4.

25. Peng KT, Chen CF, Chu IM, Li YM, Hsu WH, Hsu RW, et al. Treatment of osteomyelitis with teicoplanin-encapsulated biodegradable thermosensitive hydrogel nanoparticles. Biomaterials 2010;31:5227-36.

26. Eder C, Schenk S, Trifinopoulos J, Külekci B, Kienzl M, Schildböck S, et al. Does intrawound application of vancomycin influence bone healing in spinal surgery? Eur Spine J 2015 Apr 24. [Epub ahead of print]

27. Masquelet AC, Fitoussi F, Begue T, Muller GP. Reconstruction of the long bones by the induced membrane and spongy autograft. Ann Chir Plast Esthet 2000;45:34653. [Abstract]

28. Pelissier P, Masquelet AC, Bareille R, Pelissier SM, Amedee $\mathrm{J}$. Induced membranes secrete growth factors including vascular and osteoinductive factors and could stimulate bone regeneration. J Orthop Res 2004;22:73-9.

29. Towler DA. The osteogenic-angiogenic interface: novel insights into the biology of bone formation and fracture repair. Curr Osteoporos Rep 2008;6:67-71.

30. Del Favero A, Patoia L, Bucaneve G, Biscarini L, Menichetti F. Leukopenia with neutropenia associated with teicoplanin therapy. DICP 1989;23:45-7.

31. Zhang Z, Wang X, Luo F, Yang H, Hou T, Zhou Q, et al. Effects of rifampicin on osteogenic differentiation and proliferation of human mesenchymal stem cells in the bone marrow. Genet Mol Res 2014;13:6398-410. 